\title{
Viability of Pony Stallion Semen in Different Temperature and Dilution
}

\author{
Janislene Mach Trentin', Murilo Farias Rodrigues', Gilson Antonio Pessoa', Mariani Farias Fiorenza', \\ Ricardo Olimpio Schenatto', Laurence Boligon de Araujo', Karine Vargas Aires² \& Mara lolanda Batistella Rubin ${ }^{3}$
}

\begin{abstract}
Background: Artificial insemination and transport of cooled semen has been routinely used in equine industry in the past 20 years. However, more investigations are needed regarding the methods for long time storage in pony stallion semen. The effect of dilution and cooling temperature on $\mathrm{pH}$, sperm motility, membrane integrity and mitochondrial activity were investigated before and after cooling of stallion semen. Materials, Methods \& Results: Two ejaculates each from nine Brazilian ponies were diluted in a nonbuffered powder milk extender cooled at $5^{\circ} \mathrm{C}$ or $15^{\circ} \mathrm{C}$ for $48 \mathrm{~h}$ using three different dilutions $(1: 1,1: 2$ or 1:3). Data were assessed by analysis of variance and the rate comparison was performed using the Duncan test. Samples diluted $1: 1$ at $5^{\circ} \mathrm{C}$ or $15^{\circ} \mathrm{C}$ showed higher $\mathrm{pH}$ values $(7.63 \pm 0.34$ e $7.57 \pm 0.27)$ and lower progressive motility $(10.3 \pm 11.05,17.08 \pm 9.95)$. All samples cooled at $15^{\circ} \mathrm{C}$ also showed lower incidence of morphologically altered spermatozoa $(1: 1=55.84 \% ; 1: 2=51.84 \% ; 1: 3=49.95 \%)$ $[P<0.01]$. Mitochondrial activity was higher on the $1: 3$ dilution $(0.86 \pm 0.19 \mathrm{~nm})$ at $5^{\circ} \mathrm{C}$ and on the $1: 1(0.89 \pm 0.23 \mathrm{~nm}), 1: 2(0.93 \pm 0.2 \mathrm{~nm})$ and $1: 3(0.92 \pm 0.2 \mathrm{~nm})$ dilutions at $15^{\circ} \mathrm{C}$. Progressive motility was higher when semen was diluted $1: 3$ and cooled at $15^{\circ} \mathrm{C}(42.22 \pm 12.38 ; P<0.05)$. Considering mitochondrial activity, similar results were observed when different dilutions of semen were used $(P>$ $0.05)$ despite time and temperature. The $\mathrm{pH}$, progressive motility, mitochondrial activity and membrane integrity remained similar $(P>0.05)$ on fresh semen samples independent of the dilution grade used. The best results were obtained when semen was diluted 1:3 and cooled at $15^{\circ} \mathrm{C}$. All dilution grades were safe for fresh semen and $\mathrm{pH}$ wasincreased when semen was diluted and cooled for $48 \mathrm{~h}$.

Discussion: The methodology used to collect and process equine semen and semen from ponies is practically the same. Equine semen when sent for artificial insemination is usually cooled to $5^{\circ} \mathrm{C}$. Our results showed that cooling reduces sperm viability, which has also been demonstrated by other studies. In contrast, the best cooling temperature was at $15^{\circ} \mathrm{C}$. However, it is easier to keep the temperature at $5^{\circ} \mathrm{C}$ during transport, due to the large temperature oscillation that may occur during transportation. The semen of ponies can tolerate cooling at both 5 and $15^{\circ} \mathrm{C}$. The $1: 3$ dilution cooled to $15^{\circ} \mathrm{C}$ provided better viability of pony sperm, and more stable $\mathrm{pH}$ during $48 \mathrm{~h}$ of cooling. Dilution 1:1 should not be used for cooling in powdered skim milk extender.
\end{abstract}

Keywords: concentration, cooling, equine, extender, semen.

${ }^{1}$ Programa de Pós-graduação em Medicina Animal: Equinos (PPGMAE), Faculdade de Veterinária (FaVet), Universidade Federal do Rio Grande do Sul (UFRGS), Porto Alegre, RS, Brazil. ${ }^{2}$ Laboratório de Embriologia Animal, Departamento de Clinica de Grandes Animais \& ${ }^{3}$ Departamento de Clinica de Grandes Animais, Universidade Federal de Santa Maria (UFSM), Santa Maria, RS. CORRESPONDENCE: J.M. Trentin [janislenetrentin@yahoo.com.br - Tel.: +55 (55) 996077577]. Programa de Pós-graduação em Medicina Animal: Equinos (PPGMAE), FaVet, UFRGS. Av. Bento Gonçalves n. 9090. Bairro Agronomia. CEP 91540-000 Porto Alegre, RS, Brazil. 


\section{INTRODUCTION}

Transport of cooled semen has been routinely used in the past 20 years. Today, most equine breeder associations allow the use of artificial insemination, and owners have enjoyed the benefits of this biotechnology [1]. The focus of research for over two decades has been optimization of protocols for equine cooledshipped semen [11] because temperature, storage time, extender, dilution and cooling curve affect fertilizing capacity [34].

The maintenance of sperm viability for at least $24 \mathrm{~h}$ is essential in the equine reproduction [31]; in Brazil, however, considering distance and logistics, this period should be extended to $48 \mathrm{~h}$. It has already been proven that there is a decrease in motility, membrane integrity [24] and fertilizing ability [22] of equine spermatozoa during cooled-storage. Also occur during cooled storage, the "cold shock" [5,9] and other changes such as lipid peroxidation [14], modifications in $\mathrm{pH}$ [6], ATP depletion [7], oxidative phosphorylation [27], and bacterial contamination [30].

The interval between collection and use leads to a constant search to improve maintenance of sperm viability. Besides these facts, it is well known that there are variability from stallion to stallion and differences between breeds. The search for knowing the reproductive parameters of the breeds is important in the identification of individuals with high and low reproductive potential. The breeding of ponies gained remarkable popularity in recent years becoming an important trade field for breeders and professionals. However, this specie still lacks studies that address issues mainly related to semen quality. In horses, there is extensive literature on reproductive biotechnologies related to handling, cooling, transportation and freezing, which has not occurred with the pony. Because of that, our goal was to test the effect of temperature $\left(5^{\circ}\right.$ or $15^{\circ} \mathrm{C}$ ) and different dilutions on semen for $48 \mathrm{~h}$ on sperm viability of Brazilian pony stallions.

\section{MATERIALS AND METHODS}

\section{Place and Animals}

This study was conducted between January and June 2013 at the Laboratory of Animal Embryology of the Federal University of Santa Maria (UFSM), Santa Maria/RS, Brazil. Nine pony stallions of the Brazilian breed, aged 9 to 13 years had their semen collected routinely with an artificial vagina before and during the study.

\section{Semen collection}

Two ejaculates from each pony were obtained with a Hannover model artificial vagina. Semen collection was performed as previously described [17]. Ejaculates were filtered with sterile gauze to separate the gel-free portion of the ejaculate. Then the volume, appearance and color were macroscopically evaluated.

\section{Semen extenders}

The extender was composed of $2.4 \mathrm{~g}$ of powdered skim milk, $4.9 \mathrm{~g}$ of glucose ${ }^{1}$ and $95 \mathrm{~mL}$ of purified water [adapted from 15]. Each ejaculate was divided into six fractions, and two of these fractions were extended 1:1 (semen:extender), 1:2 and 1:3, respectively.

\section{Semen analyses}

Immediately after dilution motility, $\mathrm{pH}$, concentration, membrane function (hypoosmotic - HOST), and mitochondrial activity (MTT) of samples were evaluated. After initial analysis, samples were stored at $5^{\circ} \mathrm{C} \pm 1.6$ in a refrigerator or at $15^{\circ} \mathrm{C}$ in a special cooling box for semen (Botubox ${ }^{\circledR}$ ) for 24 and $48 \mathrm{~h}$. The cooling rate in the refrigerator ranged from 0.6 to $0.8^{\circ} \mathrm{C} / \mathrm{min}$. Evaluations were repeated after 24 and 48 h of cooling. Sample evaluation was conducted after 15 min of warming on a platinum device adjusted to $37^{\circ} \mathrm{C}$. The $\mathrm{pH}$ was measured in freshly diluted samples $(\mathrm{pH}$ Meter Tec-2, Tecnal) and after $24 \mathrm{~h}$ and $48 \mathrm{~h}$ of cooling.

Sperm concentration was determined using a Neubauer haemocytometer counting chamber. Sperm motility was evaluated according to described in the literature [33]. Assessment of sperm function was performed following protocol [18]. Sperm cell morphology was classified according to Neild et al. [23].

To assess mitochondrial activity [2], a sample of each group was centrifuged $10 \mathrm{~min}$ at $600 \mathrm{x} \mathrm{g}$, and concentration was adjusted to $100 \times 10^{6} \mathrm{sptz} / \mathrm{mL}$. Two aliquots of $200 \mu \mathrm{L}$ containing $100 \times 10^{6} \mathrm{sptz} / \mathrm{mL}$ were deposited in $2 \mathrm{~mL}$ micro centrifuge tubes. Tetrazolium solution, $20 \mu \mathrm{L}$ ( $5 \mathrm{mg} / \mathrm{mL}$ ) thiazolyl blue tetrazolium bromide ${ }^{2}$ in saline PBS was added to these tubes and they were incubated for $30 \mathrm{~min}$ in a water bath at $37^{\circ} \mathrm{C}$. The micro centrifuge tubes were centrifuged at $12,000 \mathrm{x} g$ for $5 \mathrm{~min}$ after addition of $200 \mu \mathrm{L}$ of a $0,04 \mathrm{~N} \mathrm{HCl}$ - isopropanol solution. The supernatant was used to measure the mitochondrial metabolic activity by UV visible spectrophotometry with 
a wave length of $540 \mathrm{~nm}$. The reference sample used (white) was the skim milk extender solution with glucose, tetrazolium and $0,04 \mathrm{~N} \mathrm{HCl}$-isopropanol. Aliquots of each stallion were analyzed in duplicate.

\section{Statistical analysis}

The SAS ${ }^{\circledR}$ software (version 9.2, SAS Institute Inc., Cary, NC, USA) was used for statistical analysis. Experimental design was completely randomized. Data were analyzed by analysis of variance (ANOVA) and the rate comparison was performed using the Duncan test.

\section{RESULTS}

The average ejaculate volume was $15.69 \pm$ $12.81 \mathrm{~mL}$, and total concentration was $330.83 \pm 208.79$ x $10^{6} \mathrm{sptz} / \mathrm{mL}$. Average concentration and standard deviation of the 1:1, 1:2 and 1:3 dilutions was 165.41 $\pm 104.39 \times 10^{6} \mathrm{sptz} / \mathrm{mL}, 110.27 \pm 69.59 \times 10^{6} \mathrm{sptz} / \mathrm{mL}$, and $82.70 \pm 52.19 \times 10^{6} \mathrm{sptz} / \mathrm{mL}$, respectively. Mean sample volume of dilutions $1: 1,1: 2$ and $1: 3$ in the graduated tubes was $10.46 \pm 8.54 \mathrm{~mL}, 15.69 \pm 12,81$ $\mathrm{mL}$ and $20.93 \pm 17.09 \mathrm{~mL}$.
After semen collection, temperature and dilutions used did not interfere with progressive motility, hypoosmotic test, mitochondrial activity and $\mathrm{pH}(P>$ $0.05)$ among the three semen dilutions. Progressive motility was higher (PM, $P<0.0001)$ and $\mathrm{pH}$ was lower $(P<0.001)$ when semen was diluted 1:2 and 1:3 at both temperatures $\left(5^{\circ} \mathrm{C}\right.$ and $\left.15^{\circ} \mathrm{C}\right)$ compared to $1: 1$ dilution. The highest percentage of sperm cells with intact membranes was observed at $15^{\circ} \mathrm{C}$, but did not differ between the three dilutions (Table 1). Mitochondrial activity was higher $(P=0.0006)$ at $15^{\circ} \mathrm{C}$. Higher $\mathrm{pH}$ values were detected on $1: 1$ dilution at $5^{\circ} \mathrm{C}$ and $15^{\circ} \mathrm{C}$.

Evaluation of three different dilutions of cooled semen after 24 and $48 \mathrm{~h}$ showed that the 1:1 dilution, independent of temperature (Table 2) had a higher $\mathrm{pH}(P<0.01)$ and a lower percentage of progressive motility. The 1:2 and 1:3 dilutions presented similar progressive motility and $\mathrm{pH}$ among treatments at 24 h. Functional membrane integrity and mitochondrial activity results were similar on all three dilutions after $24 \mathrm{~h}$ and $48 \mathrm{~h}$ of cooling.

Table 1. Means and standard deviation of progressive motility, HOST test, mitochondrial activity and $\mathrm{pH}$ on fresh and $48 \mathrm{~h}$ cooled $\left(5^{\circ} \mathrm{C}\right.$ and $\left.15^{\circ} \mathrm{C}\right)$ samples of three dilutions of Brazilian pony semen.

\begin{tabular}{|c|c|c|c|c|}
\hline $\begin{array}{c}\text { Dilution } \\
\text { Preservation }\end{array}$ & $1: 1$ & $1: 2$ & $1: 3$ & $P$ Value \\
\hline \multicolumn{5}{|c|}{ Progressive Motility } \\
\hline Fresh & $68.61 \pm 5.63^{\mathrm{a}}$ & $68.33 \pm 7.07^{\mathrm{a}}$ & $68.88 \pm 5.3^{\mathrm{a}}$ & \\
\hline $5^{\circ} \mathrm{C}$ & $10.3 \pm 11.05^{\mathrm{e}}$ & $30.55 \pm 14.91^{\mathrm{d}}$ & $36.94 \pm 14^{\mathrm{cd}}$ & $<0.0001$ \\
\hline $15^{\circ} \mathrm{C}$ & $17.08 \pm 9.95^{\mathrm{b}}$ & $35.97 \pm 15.80^{\mathrm{cd}}$ & $42.22 \pm 12.38^{c}$ & \\
\hline \multicolumn{5}{|c|}{ Hypoosmotic } \\
\hline Fresh & $62.22 \pm 9.4^{c}$ & $61 \pm 9^{c}$ & $60.88 \pm 11.11^{\mathrm{c}}$ & \\
\hline $5^{\circ} \mathrm{C}$ & $30.16 \pm 14.31^{\mathrm{e}}$ & $35.55 \pm 13.2^{\mathrm{e}}$ & $35.75 \pm 13.73^{e}$ & $<0.0001$ \\
\hline $15^{\circ} \mathrm{C}$ & $44.16 \pm 14.59^{\mathrm{d}}$ & $48.16 \pm 13.52^{\mathrm{d}}$ & $50.05 \pm 11.36^{\mathrm{d}}$ & \\
\hline \multicolumn{5}{|c|}{$\operatorname{MTT}(\mathrm{nm})$} \\
\hline Fresh & $1 \pm 0.26^{\mathrm{e}}$ & $0.91 \pm 0.18^{\mathrm{ed}}$ & $0.93 \pm 0.17^{\mathrm{ed}}$ & \\
\hline $5^{\circ} \mathrm{C}$ & $0.74 \pm 0.2^{\mathrm{c}}$ & $0.84 \pm 0.22^{\mathrm{bc}}$ & $0.86 \pm 0.19^{\text {cde }}$ & 0.0006 \\
\hline $15^{\circ} \mathrm{C}$ & $0.89 \pm 0.23^{\mathrm{de}}$ & $0.93 \pm 0.2^{\text {de }}$ & $0.92 \pm 0.20^{\mathrm{de}}$ & \\
\hline \multicolumn{5}{|c|}{$p H$} \\
\hline Fresh & $7.25 \pm 0.17^{a}$ & $7.13 \pm 0.21^{\mathrm{a}}$ & $7.12 \pm 0.15^{\mathrm{a}}$ & \\
\hline $5^{\circ} \mathrm{C}$ & $7.63 \pm 0.34^{\mathrm{e}}$ & $7.46 \pm 0.21^{\mathrm{cd}}$ & $7.38 \pm 0.11^{\mathrm{bc}}$ & $<0.0001$ \\
\hline $15^{\circ} \mathrm{C}$ & $7.57 \pm 0.27^{\mathrm{de}}$ & $7.37 \pm 0.22^{\mathrm{bc}}$ & $7.31 \pm 0.15^{\mathrm{c}}$ & \\
\hline
\end{tabular}

a,b,c, Different letters on lines and columns mean $P<0.05$. 
Table 2. Means and standard deviation of progressive motility, HOST test, mitochondrial activity and $\mathrm{pH}$ of three dilutions of Brazilian pony semen evaluated after collection (fresh) and $24 \mathrm{~h}$ and $48 \mathrm{~h}$ after cooling at $5^{\circ} \mathrm{C}$ or $15^{\circ} \mathrm{C}$.

\begin{tabular}{|c|c|c|c|c|}
\hline $\begin{array}{c}\text { Dilution } \\
\text { Preservation }\end{array}$ & $1: 1$ & $1: 2$ & $1: 3$ & $P$ Value \\
\hline \multicolumn{5}{|c|}{ Progressive Motility } \\
\hline Fresh & $68.61 \pm 5.63^{\mathrm{a}}$ & $68.33 \pm 7.07^{a}$ & $68.88 \pm 5.3^{\mathrm{a}}$ & $<0.0001$ \\
\hline $24 \mathrm{~h}$ & $19.16 \pm 10.85^{\mathrm{e}}$ & $39.72 \pm 13.51^{\mathrm{dc}}$ & $43.61 \pm 11.62^{\mathrm{d}}$ & \\
\hline $48 \mathrm{~h}$ & $8.22 \pm 8.092^{b}$ & $26.8 \pm 14.79^{\mathrm{f}}$ & $35.55 \pm 13.97^{c}$ & \\
\hline \multicolumn{5}{|c|}{ Hypoosmotic } \\
\hline Fresh & $62.22 \pm 9.4^{\mathrm{a}}$ & $61 \pm 9^{a}$ & $60.88 \pm 11.11^{\mathrm{a}}$ & $<0.0001$ \\
\hline $24 \mathrm{~h}$ & $43.91 \pm 14.81^{\mathrm{de}}$ & $46.05 \pm 13.33^{\mathrm{e}}$ & $46.52 \pm 13.56^{\mathrm{e}}$ & \\
\hline $48 \mathrm{~h}$ & $30.41 \pm 14.33^{c}$ & $37.66 \pm 15^{\mathrm{cd}}$ & $39.27 \pm 14.57^{\mathrm{ed}}$ & \\
\hline \multicolumn{5}{|c|}{$M T T(n m)$} \\
\hline Fresh & $1 \pm 0.26^{\mathrm{a}}$ & $0.91 \pm 0.18^{\mathrm{abc}}$ & $0.93 \pm 0.17^{\mathrm{ab}}$ & 0.03 \\
\hline $24 \mathrm{~h}$ & $0.86 \pm 0.21^{\mathrm{ac}}$ & $0.9 \pm 0.23^{\mathrm{abc}}$ & $0.9 \pm 0.21^{\mathrm{abc}}$ & \\
\hline $48 \mathrm{~h}$ & $0.78 \pm 0.24^{\mathrm{c}}$ & $0.87 \pm 0.2^{\mathrm{abc}}$ & $0.89 \pm 0.19^{\mathrm{abc}}$ & \\
\hline \multicolumn{5}{|c|}{$p H$} \\
\hline Fresh & $7.25 \pm 0.17^{\mathrm{ab}}$ & $7.13 \pm 0.21^{\mathrm{a}}$ & $7.12 \pm 0.15^{\mathrm{a}}$ & $<0.001$ \\
\hline $24 \mathrm{~h}$ & $7.65 \pm 0.34^{\mathrm{e}}$ & $7.45 \pm 0.24^{\mathrm{cd}}$ & $7.39 \pm 0.12^{\mathrm{bc}}$ & \\
\hline $48 \mathrm{~h}$ & $7.55 \pm 0.27^{\mathrm{de}}$ & $7.39 \pm 0.2^{\mathrm{bc}}$ & $7.3 \pm 0.14^{\mathrm{b}}$ & \\
\hline
\end{tabular}

a,b,c Different letters between lines and columns mean $P<0.05$.

Furthermore, after $48 \mathrm{~h}$ of cooling a higher percentage of cells with progressive motility was observed on dilution 1:3 $(P<0.05)$. Dilutions 1:2 and 1:3 showed lower $\mathrm{pH}$.

Fresh semen showed similar results between dilutions (Figure 1). At $24 \mathrm{~h}$ and $48 \mathrm{~h}$, the 1:1 dilution showed lower progressive motility at both temperatures $\left(15^{\circ} \mathrm{C}\right.$ and $\left.5^{\circ} \mathrm{C}\right)$. At $24 \mathrm{~h}$, there was no difference in progressive motility at $5^{\circ} \mathrm{C}$ or $15^{\circ} \mathrm{C}(P<0.005)$, motility started to improve at 1:2 dilution. At $48 \mathrm{~h}, 1: 3$ dilution at $15^{\circ} \mathrm{C}$ showed higher progressive motility than at $5^{\circ} \mathrm{C}(P<0.001)$.

The hypoosmotic swelling test demonstrated that better results were achieved at $15^{\circ} \mathrm{C}$ after $24 \mathrm{~h}$ and $48 \mathrm{~h}$ of cooling. Results were similar between dilutions (Figure 2) and fresh semen at this temperature.

Results of the mitochondrial activity evaluation of the diluted sperm samples obtained by absorbance reading over time and temperature (Figure 3), demonstrated similarity between dilutions in fresh semen and cooled samples ( $24 \mathrm{~h}$ and $48 \mathrm{~h}$ ).

The $\mathrm{pH}$ of fresh semen was lower than of the diluted samples after $24 \mathrm{~h}$ and $48 \mathrm{~h}$ of cooling, with no significant difference between dilutions (Figure 4). Dilution 1:1 showed higher $\mathrm{pH}$ and similar results were seen on $1: 2$ and $1: 3$ dilutions at $5^{\circ} \mathrm{C}$ or $15^{\circ} \mathrm{C}$ at $24 \mathrm{~h}$ and $48 \mathrm{~h}$ of cooling.
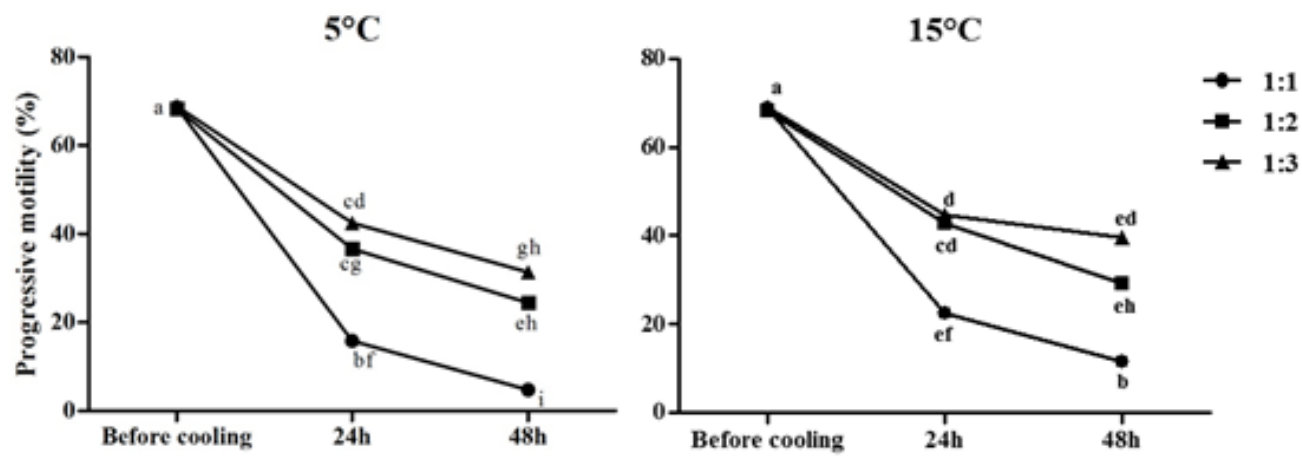

Figure 1. Progressive motility of Brazilian pony sperm diluted with a skim milk-based extender at three different dilutions $(1: 1,1: 2,1: 3)$ and cooled at $5^{\circ} \mathrm{C}$ or $15^{\circ} \mathrm{C}(P<0.001)$. 

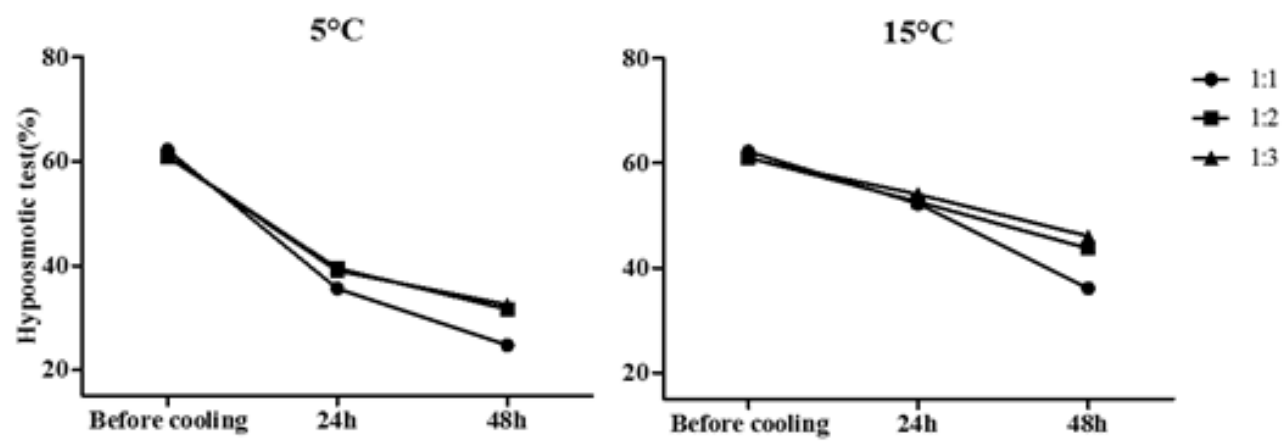

Figure 2. Percentage of swollen sperm cells on three different dilutions of fresh and cooled Brazilian pony semen samples on the hypoosmotic test $(P<0.001)$.
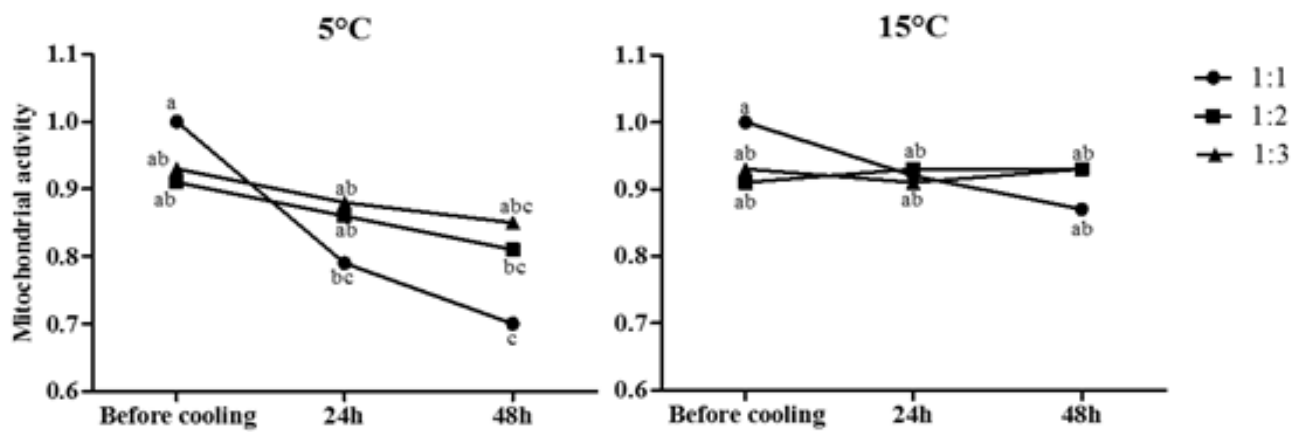

Figure 3. Mitochondrial activity of sperm cells from Brazilian ponies at three different dilutions after collection and cooled at $5^{\circ} \mathrm{C}$ or $15^{\circ} \mathrm{C}(P=0.049)$.
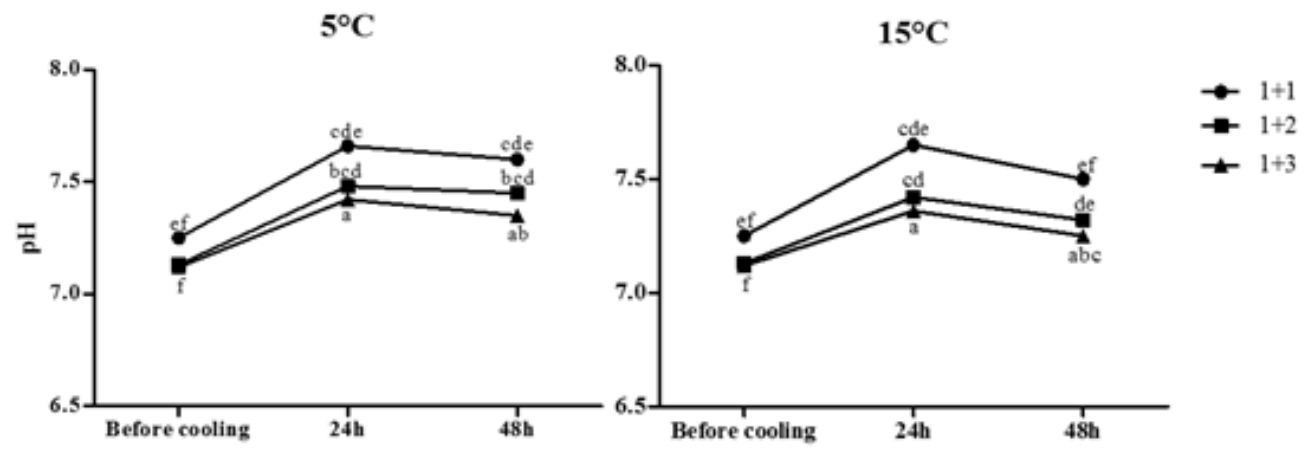

Figure 4. $\mathrm{pH}$ of fresh and cooled semen of Brazilian pony sperm on three different dilutions after $24 \mathrm{~h}$ and $48 \mathrm{~h}$, at $5^{\circ} \mathrm{C}$ or $15^{\circ} \mathrm{C}(P<0.0001)$.

\section{DISCUSSION}

Equine semen when stored or shipped is usually held for $12 \mathrm{~h}$ to $48 \mathrm{~h}$ at $5^{\circ} \mathrm{C}$. This is due to the ease of maintaining the temperature around $5^{\circ} \mathrm{C}$. The results showed that cooling reduces semen viability. This study; moreover, showed better results when semen diluted in powdered skim milk was maintained at $15^{\circ} \mathrm{C}$, agreeing with previous reports [29]. These authors, regardless of extender used, achieved higher motility on semen samples stored at $20^{\circ} \mathrm{C}$ or $15^{\circ} \mathrm{C}$ than at $10^{\circ} \mathrm{C}$ or $5^{\circ} \mathrm{C}$.

Progressive motility of pony spermatozoa after 24 h of cooling was similar between $5^{\circ} \mathrm{C}$ and $15^{\circ} \mathrm{C}$. However, in equine spermatozoa was demonstrated $[32,33]$ that cooling at $4^{\circ} \mathrm{C}$ and $5^{\circ} \mathrm{C}$ for $24 \mathrm{~h}$ resulted in greater sperm motility than at $20^{\circ} \mathrm{C}$ or $25^{\circ} \mathrm{C}$, with a pregnancy rate of $73 \%$ for both temperatures. Price et al. [28] found no difference between progressive motility of diluted equine semen kept at $5^{\circ} \mathrm{C}$ or $15^{\circ} \mathrm{C}$ after $48 \mathrm{~h}$ of storage. It remains 
unclear whether the addition of gentamicin, which blocks bacterial growth, may have favored this result. The hypoosmotic swelling test demonstrated that better results were achieved at $15^{\circ} \mathrm{C}$ after $24 \mathrm{~h}$ and $48 \mathrm{~h}$ of cooling. The percentage of sperm with intact membranes may prove to be one of the more important criteria for predicting potential fertility of cool-stored semen in stallions [16]. In 1998, significant reduction was observed [3] in fertility when semen was stored for $24 \mathrm{~h}$ at $20^{\circ} \mathrm{C}$, compared with storage at $5^{\circ} \mathrm{C}$. Love et al., [19] using refrigerated semen of 18 stallions diluted in a skim milk extender at $5^{\circ} \mathrm{C}$ or $20^{\circ} \mathrm{C}$ for $7 \mathrm{~h}$ to $46 \mathrm{~h}$, observed higher sperm chromatin integrity at $20^{\circ} \mathrm{C}$. Cooling between $4^{\circ} \mathrm{C}$ and $5^{\circ} \mathrm{C}$ reduces sperm metabolic activity, bacterial growth, and keeps sperm viable for long periods [13]. Similar results were observed during storage of the testis-epididymis complex at $5^{\circ} \mathrm{C}$, which provided better preservation of epididymal sperm than storage at room temperature [21].

In a laboratory setting, equine semen stored for $72 \mathrm{~h}$ at $5^{\circ} \mathrm{C}$ without air exposure or at $15^{\circ} \mathrm{C}$ with air exposure showed similar fertility results [34]. In vitro studies conducted with stallion semen diluted in skim milk diluents and stored for $24 \mathrm{~h}$ in different types of dischargeable recipients, and at different temperatures suggest that motility is affected when the internal temperature of the recipient is lower than $2^{\circ} \mathrm{C}$ and above $20^{\circ} \mathrm{C}[4,20]$. Furthermore, equine semen tolerates large cooling rates and storage temperatures $[4,34]$, which was also proved in pony semen in this study.

Progressive motility evaluation of fresh diluted semen was similar between 1:1, 1:2 and 1:3 dilutions. After $24 \mathrm{~h}$ and $48 \mathrm{~h}$ of cooling, the 1:1 dilution had lower progressive motility $(P<0.001)$. Progressive motility was similar at $1: 2$ and $1: 3$ dilutions after $24 \mathrm{~h}$ cooling, and at $48 \mathrm{~h}$, the $1: 3$ dilution resulted in higher progressive motility. Thus, for transportation until 48 $\mathrm{h}, 15^{\circ} \mathrm{C}$ and $1: 3$ dilutions would be more indicated, since these solutions showed the least $\mathrm{pH}$ variability, indicating that as the dilution increases cooled sperm viability is favored. Dilution of equine semen in a commercial extender to very low sperm concentrations had only minor effects on sperm quality [10]. Jasko et al., [12] using an egg yolk extender, observed that semen dilutions from 1:4 to $1: 19$ were appropriate to preserve equine semen at $5^{\circ} \mathrm{C}$ and that increasing the dilution favors sperm viability.

The positive effects of extenders are based on pH control, osmolarity and energy supply [25]. The absence of a buffering component in the extender used in this study may have led to the $\mathrm{pH}$ variation observed in the cooled semen. Measured $\mathrm{pH}$ clearly indicates that storage time and temperature influence the $\mathrm{pH}$ of cooled semen in a skim milk, glucose-based extender. $\mathrm{pH}$ increased the first $24 \mathrm{~h}$ and declined at $48 \mathrm{~h}$ of storage at $5^{\circ} \mathrm{C}$ and $15^{\circ} \mathrm{C}$, and this may have reduced the progressive motility further than the expected reduction in motility due to cooling and time. At $5^{\circ} \mathrm{C}$, a higher $\mathrm{pH}$ was maintained at $24 \mathrm{~h}$ and $48 \mathrm{~h}$, similar to that observed on fresh semen samples. This suggests that the addition of a buffer to the extender is required so that $\mathrm{pH}$ does not have a negative influence on the viability of spermatozoa.

The increase in $\mathrm{pH}$ observed during cooling may be related to the percentage of viable spermatozoa during storage. Lower storage temperature decreases metabolic rate, slows chemical reactions and reduces bacterial growth, extending the life of fertile spermatozoa [26]. In one research with stallion sperm, $\mathrm{pH}$ was not a significant source of variation in motility and live sperm percentage over different cooling periods [6]. In our study, samples with higher motility had lower $\mathrm{pH}$. This was attributed to metabolism reduction induced by cooling. The low $\mathrm{pH}$ may be related to the production of hydrogen ions and lactic acid from sperm metabolism. Of our knowledge we support that there are similarities with queries related to Equus ferus caballus.

\section{CONCLUSION}

Progressive motility, $\mathrm{pH}$, membrane integrity and mitochondrial activity of pre-cooled pony semen diluted in a powdered skim milk-based extender were not affected by dilution 1:1, 1:2 or 1:3. However, the $1: 3$ dilution cooled at $15^{\circ} \mathrm{C}$ provided better viability of pony sperm, and more stable $\mathrm{pH}$ during $48 \mathrm{~h}$ of cooling. Dilution 1:1 should not be used for cooling in powdered skim milk extender. Increasing the dilution does not interfere with mitochondrial activity and promotes sperm viability. Cooling at $5^{\circ} \mathrm{C}$ increases the $\mathrm{pH}$ of diluted semen.

\section{MANUFACTURERS}

${ }^{1}$ Merck KGaA. Darmstadt, Germany.

${ }^{2}$ Sigma Aldrich Co. St. Louis, MO, USA.

Funding. Coordenação de Aperfeiçoamento de Pessoal de Nível Superior - CAPES, Brasília, DF, Brazil and Laboratório de Embriologia Animal (EMBRYOLAB), UFSM, Santa Maria, RS, Brazil. 
Ethical approval. The Ethical and Animal Research Committee from the Federal University of Santa Maria (UFSM) [protocol number 065/2013] approved all procedures involving the pony stallions used in this study.
Declaration of interest. The authors report no conflicts of interest. The authors alone are responsible for the content and writing of the paper.

\section{REFERENCES}

1 Aurich J.E. \& Aurich C. 2006. Developments in European horse breeding and consequences for veterinarians in equine reproduction. Reproduction in Domestic Animals. 41: 275-279.

2 Aziz D.M., Ahlswede L. \& Enbergs H. 2005. Application of MTT reduction assay to evaluate equine sperm viability. Theriogenology. 64: 1350-1356.

3 Ball B.A. 1998. Evaluation and use of transported equine semen. In: Equine Assisted Reproductive Technology Workshop (Davis, USA). pp.18-24.

4 Brinsko S.P., Rowan K.R., Varner D.D. \& Blanchard T.L. 2000. Effects of transport container and ambient storage temperature on motion characteristics of equine spermatozoa. Theriogenology. 53: 1641-1655.

5 Bogart R. \& Mayer D.T. 1950. The effects of egg yolk on the various physical and chemical factors detrimental to spermatozoa viability. Journal of Animal Science. 9: 143-152.

6 Crespilho A.M., Spizziri B.E., Meyers M. \& Graham J.K. 2013. The effect of cholesterol addition, buffer, and pH on equine sperm stored at $5^{\circ} \mathrm{C}$. Journal of Equine Veterinary Science. 33(8): 663-666.

7 Gibb Z. \& Aitken R.J. 2016. The Impact of Sperm Metabolism during In Vitro Storage: The Stallion as a Model. BioMed Research International. 2016: 1-8.

8 Gottschalk M., Sieme H., Martinsson G. \& Ottmar D. 2016. Analysis of breed effects on semen traits in light horse, warmblood, and draught horse breeds. Theriogenology. 85: 1375-1381.

9 Harrison R.A.P. \& White I.G. 1972. Glycolytic enzymes in the spermatozoa and cytoplasmic droplets of bull, boar and ram, and their leakage after shock. Journal of Reproduction and Fertility. 30: 105-115.

10 Hayden S.S., Blanchard T.L., Brinsko S.P., Varner D.D., Hinrichs K. \& Love C.C. 2015. The "dilution effect" in stallion sperm. Theriogenology. 83: 772-777.

11 Heckenbichler S., Deichsel K., Peters P. \& Aurich C. 2011. Quality and fertility of cooled-shipped stallion semen at the time of insemination. Theriogenology. 75: 849-856.

12 Jasko D.J., Hathaway J.A., Schaltenbrand V.L., Simper W.D. \& Squires E.L. 1992. Effect of seminal plasma and egg yolk on motion characteristics of cooled stallion spermatozoa. Theriogenology. 37: 1241-1252.

13 Katila T. 1997. Procedures for handling fresh stallion semen. Theriogenology. 48: 1217-1227.

14 Kankofer M., Kolm G., Aurich J. \& Aurich C. 2005. Activity of glutathione peroxidase, superoxide dismutase and catalase and lipid peroxidation intensity in stallion semen during storage at $5^{\circ} \mathrm{C}$. Theriogenology. 63: 1354-1365.

15 Kenney R.M., Bergman R.V., Cooper W.L. \& Morse G.M. 1975. Minimal contamination techniques for breeding mares: techniques and preliminary findings. In: Proceedings of the 21st Annual Convention of the American Association of Equine Practitioners (Boston, USA). pp.327-336.

16 Kiser A.M., Brinsko S.P., Love C.C., Varner D.D., Sudderth K. \& Blanchard T.L. 2014. Relationship of Sperm Quality to Fertility after 4 Days of Cooled Storage of Equine Semen. Journal of Equine Veterinary Science. 34: 602-605.

17 Klug E. \& Sieme H. 2003. Samenübertragungbeim Pferd in Theorie und Praxis. $5^{\circ}$ volliguberarbeitete Auflage. Hannover: Verlag M. \& H. Alfeld, 144p.

18 Lomeo A.M. \& Giambersio A.M. 1991. 'Water-test': a simple method to assess sperm-membrane integrity. International Journal of Andrology. 14: 278-282.

19 Love C.C., Thompson J.A., Lowry V.K. \& Varner D.D. 2001. The relationship between chromatin quality and fertility of chilled stallion sperm. In: Proceedings of the 47th Annual Convention of the American Association of Equine Practitioners (San Diego, USA). pp.229-231.

20 Malmgren L. 1998. Effectiveness of two systems for transporting equine semen. Theriogenology. 50: 833-839.

21 Monteiro G.A., Guasti P.N., Rocha A.S., Martin I., Sancler-Silva Y.F.R., Dell'Aqua C.P.F., Dell'Aqua Jr. J.A. \& Papa F.O. 2013. Effect of storage time and temperature of equine epididymis on the viability, motion parameters, and freezability of epididymal sperm. Journal of Equine Veterinary Science. 33(3): 169-173. 
22 Moran D.M., Jasko D.J., Squires E.L. \& Amann R.P. 1992. Determinationof temperature and cooling rate which induce cold shock in stallionspermatozoa. Theriogenology. 38: 999-1012.

23 Neild D.M., Chaves M.G., Flores M., Miragaya M.H., Gonzalez E. \& Agüerro A. 2000. The host test and its relationship to fertility in the stallion. Andrology. 32: 351-355.

24 Oliveira R.A., Scarlet D., Ille N. \& Aurich C. 2017. Cooled-storage of equine semen does not induce major changes in sperm DNA methylation. Theriogenology. 89: 289-294.

25 Pagl R., Aurich J.E., Müller-Schlösser F., Kankofer M. \& Aurich C. 2006. Comparison of an extender containing defined milk protein fractions with a skim milk-base extender for storage equine semen at $5^{\circ} \mathrm{C}$. Theriogenology. 66 : 1115-1122.

26 Pickett B.W. \& Amann R.P. 1987. Extension and storage of stallion spermatozoa: a review. Journal of Equine Veterinary Science. 7: 289-302.

27 Plaza Davila J., Martin Muñoz P., Gallardo Bolaños J.M., Stout T.A.E., Gadella B.M., Tapia J.A., Balao da Silva C., Ortega-Ferrusola C. \& Peña F.J. 2016. Mitochondrial ATP is required for the maintenance of membrane integrity in stallion spermatozoa, whereas motility requires both glycolysis and oxidative phosphorylation. Reproduction. 152: 683-694.

28 Price S., Aurich J., Davies-Morel M. \& Aurich C. 2008. Effects of oxygen exposure and gentamicin on stallion semen stored at 5 and 15 degrees C. Reproduction in Domestic Animals. 43: 261-266.

29 Province C.A., Squires E.L., Pickett B.W. \& Amann R.P. 1985. Cooling rates, storage temperatures and fertility of extended equine spermatozoa. Theriogenology. 23: 925-934.

30 Ramires Neto C., Silva Y.F.R.S., Resende H.L., Guasti P.N., Monteiro G.A., Papa P.M., Dell'Aqua Junior J.A., Puoli Filho J.N.P., Alvarenga M.A. \& Papa F.O. 2015. Control methods an evaluation of bacterial growth on fresh and cooled stallion semen. Journal of Equine Veterinary Science. 35(4): 277-282.

31 Squires E.L., Pickett B.M., Graham J.K., Vanderwall D.K., Mccue P.M. \& Bruemmer J.E. 1999. Cooled and frozen stallion semen. Animal Reproduction and Biotechnology Laboratory. Colorado State University Bulletin. 9: $1-38$.

32 Varner D.D., Blanchard T.L., Love C.L., Garcia M.C. \& Kenney R.M. 1988. Effects of cooling rate and storage temperature on equine spermatozoal motility parameters. Theriogenology. 29: 1043-1053.

33 Varner D.D., Blanchard T.L., Meyers P.J. \& Meyers S.A. 1989. Fertilizing capacity of equine spermatozoa stored for 24 hours at 5 or $20^{\circ} \mathrm{C}$. Theriogenology. 32: 515-525.

34 Vidament M., Magistrini M., Le Foll Y., Levillain N., Yvon J.M., Duchamp G. \& Blesbois E. 2012. Temperatures from 4 to $15^{\circ} \mathrm{C}$ are suitable for preserving the fertilizing capacity of stallion semen stored for $22 \mathrm{~h}$ or more in inra96 extender. Theriogenology. 78: 297-307. 